\title{
Perspektywa neoinstytucjonalna w badaniach nad przemianami szkolnictwa wyższego w Polsce
}

\begin{abstract}
STRESZCZENIE. Celem artykułu jest przedstawienie neoinstytucjonalnej perspektywy analiz procesów zachodzących w polskim szkolnictwie wyższym. Pod wpływem działania społeczeństwa światowego (Meyer i in., 1997) narodowe systemy (w tym polski) stopniowo zmierzają w kierunku konwergencji. Jest to szczególnie widoczne w takich krajach, jak Polska, które po dłuższym okresie izolacji zostały wystawione na działanie procesów globalnych, przez dekady kształtujących systemy krajów Europy Zachodniej. W artykule starano się pokazać, że: a) polskie przemiany w szkolnictwie wyższym stwarzają okazję do przetestowania, a nawet rozbudowania neoinstytucjonalnej teorii w warunkach głębokich i dynamicznych przeobrażeń, które miały miejsce w kraju o bogatej tradycji akademickiej i silnej pozycji społeczności naukowej; b) badania nad współczesnymi przemianami w polskim szkolnictwie wyższym nie mogą dokonywać się w oderwaniu od jego historycznego dziedzictwa, a także politycznych warunków jego funkcjonowania przez niemal cały XX wiek. Istotnie zwiększyły one znaczenie nieformalnych, akademickich czy uczelnianych zwyczajów i obyczajów, które w trudnym okresie niedemokratycznych rządów pozwalały uczelniom w miarę normalnie funkcjonować.
\end{abstract}

SŁOWA KLUCZOWE: neoinstytucjonalizm, szkolnictwo wyższe, transformacja, Polska

\section{Wprowadzenie}

Polskie szkolnictwo wyższe jest jednym z tych obszarów życia społecznego, które w ostatnim ćwierćwieczu przeszły gwałtowne i głębokie przemiany. Ich merytokratyczny kierunek, rynkowy wymiar oraz dynamika dla wielu badaczy stały się symbolem polskiej transformacji systemowej (np. Misztal 2000; Pawłowski 2004), wprowadziły bowiem jakościową zmianę w stosunku do okresu PRL, kiedy to szkolnictwo wyższe było niewielkim państwowym systemem funkcjonującym w sta- 
tycznych warunkach państwa socjalistycznego. Obraz ten zasadniczo odbiegał od przeobrażeń, jakie zachodziły w szkolnictwie wyższym w krajach Europy Zachodniej. Polska - z powodów geopolitycznych - pozostawała w izolacji od procesów oddziałujących na zachodnie systemy szkolnictwa wyższego: umasowienia (Scott 1995), urynkowienia (Marginson 1987) czy denacjonalizacji (van der Wende 2010). W topografii zaproponowanej przez Immanuela Wallersteina (1974), gdzie świat jest podzielony na obszary centrum, pół-peryferia, peryferia, ale też obszary leżące całkowicie poza systemem, polskie szkolnictwo wyższe znajdowało się na obrzeżach światowego systemu szkolnictwa wyższego. Wprawdzie polscy naukowcy utrzymywali kontakty z zachodnimi ośrodkami, uczestniczyli w międzynarodowych programach stypendialnych, a polskie uczelnie gościły wielu badaczy z krajów Europy Zachodniej, jednak relacje na poziomie indywidualnym miały niewielkie przełożenie na politykę naukową państwa. W wymiarze systemowym oraz instytucjonalnym polskie szkolnictwo wyższe nie podlegało działaniu wspomnianych procesów transnarodowych ani też - w odróżnieniu od krajów Europy Zachodniej - nie zmierzało w kierunku stopniowej strukturalnej konwergencji (Schofer i Meyer 2005). Przełomowym dla polskiego szkolnictwa wyższego okazał się rok 1989, kiedy w wyniku zmiany systemu politycznego i gospodarczego nastąpiło otwarcie się na świat zachodni, a tym samym na obecne w nim procesy i zjawiska.

Celem niniejszego tekstu jest przedstawienie neoinstytucjonalnej perspektywy analiz procesów zachodzących w szkolnictwie wyższym, której podstawę stanowi założenie, że pod wpływem działania międzynarodowej społeczności rozumianej jako „społeczeństwo światowe” (Meyer, Boli, Thomas i Ramirez 1997) narodowe systemy szkolnictwa wyższego stopniowo zmierzają w kierunku konwergencji. Siła oddziaływania społeczeństwa światowego najlepiej widoczna jest w krajach, które przez dekady pozostawały poza sferą oddziaływania społeczeństwa światowego i nagle otworzyły się na jego działanie. Na ich przykładzie można zaobserwować swoistą presję ze strony społeczeństwa światowego, choć mówiąc o presji, nie mam na myśli tylko intencjonalnego wywierania nacisku, ale również, a może przede wszystkim, nieformalnie manifestowane oczekiwanie wobec nowego kraju, aby jego władze postępowały zgodnie z logiką stosowności (logic of appropriateness), a nie logiką konsekwencji (logic of consequence) (March i Olsen 2004: 2). Przyjęcie optyki neoinstytucjonalnej w naturalny sposób kieruje zainteresowanie badawcze na proces ścierania się tych dwóch strategii i skupia się na towarzyszących im sposobach oddziaływania społeczeństwa światowego na państwa narodowe oraz mechanizmach adaptacji nowych trendów w polityce publicznej oraz implementacji modeli organizacyjnych, zwłaszcza prób interpretacji przychodzących z zewnątrz innowacji (politycznych i instytucjonalnych) przez środowisko akademickie. Dotychczas żaden z tych procesów nie został w pełni zbadany, choć ich skutki niejednokrotnie były przedmiotem szczegółowych analiz (Boguski 2009; Dziedziczak-Foltyn 2011; Jabłecka 2007). 
Problematyka transformacji systemowej zawsze wzbudzała ogromne zainteresowanie badawcze i - jak zauważa Agnieszka Kolasa-Nowak (2005: 120) - socjologowie już od początku lat 90. dostrzegali w polskiej transformacji specyficzną, a nawet wyjątkową sytuację, która stała się „unikalnym laboratorium, pozwalającym testować istniejące modele teoretyczne, a także okazją (czy koniecznością?) do formułowania nowych modeli” (Stark 1992: 62). W tym sensie transformacja stała się także okazją do rozwinięcia refleksji teoretycznej dotyczącej szkolnictwa wyższego, które stało się miejscem niespotykanych dotąd przemian. Jednak w ramach rozbudowanego dyskursu transformacyjnego aspekt przemian w szkolnictwie wyższym, w tym przemian systemowych, nie został dostatecznie rozwinięty, zwłaszcza w przypadku refleksji teoretycznej.

Badania nad transformacją systemową początkowo prowadzone były głównie na poziomie mikro oraz mezo, ale z czasem coraz bardziej zauważalne stały się głosy (np. Sosnowska 1998) wskazujące na potrzebę rozszerzenia perspektywy i prowadzenia analiz uwzględniających kontekst globalnych zmian, które pojawiały się głównie w pracach Witolda Morawskiego, Jadwigi Staniszkis, Marka Ziółkowskiego czy Edmunda Wnuka-Lipińskiego. Wraz z rozszerzaniem się perspektywy analitycznej coraz bardziej widoczny stawał się krytyczny nurt odwołujący się do teorii systemu światowego, wskazujący na skutki (koszty) polskiej półperyferyjności i korzyści płynące dla krajów i korporacji ulokowanych w centrum systemu światowego, na co wskazywali również ekonomiści (np. Kołodko 1992; Kowalik 2000).

$\mathrm{W}$ studiach na polską transformacją uwzględniających globalne przemiany brakowało jednak pogłębionych badań nad przemianami w szkolnictwie wyższym, co po części wynikało z tego, że - jak pokazują wcześniejsze analizy (Antonowicz 2007; 2012) - szkolnictwo wyższe i badania naukowe należą do tych nielicznych dziedzin, które nie podlegały mechanizmom gospodarczej transformacji. Można nawet powiedzieć, że mechanizmy polskiej transformacji szkolnictwa wyższego są przeciwieństwem tych obowiązujących przy transformacji polskiej gospodarki. Siłą napędową przemian zachodzących w sektorze szkolnictwa wyższego nie były interesy największych państw ani korporacji rdzenia systemu światowego. Nie były też one ich bezpośrednimi beneficjentami, choć przykłady krajów azjatyckich pokazują, że duży popyt na odpłatne formy kształcenia przekłada się na finansowe korzyści uczelni amerykańskich, brytyjskich i australijskich, które otwierają zagraniczne kampusy (Wilkins i Huisman 2011). W Polsce mimo daleko idącej liberalizacji przepisów w ustawie Prawo o szkolnictwie wyższym, umożliwiających wewnętrzną i zewnętrzną prywatyzację szkolnictwa wyższego (Kwiek 2009) oraz mimo ogromnego popytu na kształcenie na poziomie wyższym żadne z wielkich edukacyjnych przedsiębiorstw (ani czołowych uniwersytetów) nie zdecydowało się wejść na polski rynek, choć warunki ku temu były niezwykle sprzyjające.

Jak wspomniano, badania nad przemianami polskiego szkolnictwa wyższego prowadzone były głównie na poziomie mikro oraz mezo i rzadko odwoływały się 
do przemian o charakterze ponadnarodowym. Wydaje się, że spojrzenie z poziomu makrostruktur mogłoby znacząco zwiększyć naszą wiedzę o mechanizmach transformacji w szkolnictwie wyższym, jednak przyjęcie - najbardziej popularnej wśród krytycznych badaczy - teorii systemu światowego (Wallerstein 1974; Zarycki 2009) nie może nas w zasadzie przybliżyć do zrozumienia mechanizmów transformacji polskiego szkolnictwa wyższego, które znacząco różnią się od mechanizmów przemian zachodzących w pozostałych gałęziach polskiej gospodarki.

\section{Neoinstytucjonalizm}

Neoinstytucjonalny nurt w socjologii wyrósł na kanwie badań edukacyjnych (np. Meyer 1977; Meyer i Rowan 1977) stanowiących część teorii organizacji ukierunkowaną na analizę wpływu procesów globalnych na strukturę oraz funkcjonowanie nowoczesnych państw. Ich pionierami byli badacze skupieni w Center of Democracy Development and the Rule of Law Freeman Spogli Institute of International Studies Uniwersytetu Stanforda, tacy jak: John Meyer, John Boli, George M. Thomas czy Francisco Ramirez. Badacze ci mieli nie tylko istotny wkład w rozwój teorii organizacji, socjologii edukacji (np. Meyer 1977; DiMaggio i Powell 1983; Meyer i Rowan 1977), ale przede wszystkim w badania nad wpływem globalnego ładu na kierunek polityki publicznej państw narodowych oraz analizę procesu rozprzestrzeniania się nowoczesnych instytucji (Thomas, Meyer, Ramirez i Boli 1987). Dla Johna Boli i George’a Thomasa (1997: 171) „,́wiat jest czymś więcej niż siecią politycznych oraz ekonomicznych interakcji, świat stał się pojedynczym »międzynarodowym społeczeństwem «", a jego siła przejawia się przez transnarodowe organizacje postrzegane jako agenci społeczeństwa światowego (agents of world society) (Ramirez i Meyer 1980; Boli i Thomas 1997), którym zresztą przypisuje się znaczący wpływ na strukturę i funkcjonowanie współczesnych państw (Boli i Thomas 1997). Dotyczy to zwłaszcza Międzynarodowego Funduszu Walutowego (MFW), Banku Światowego (BŚ) czy OECD (Organizacja Współpracy Europejskiej i Rozwoju), które według wielu badaczy (np. Meyer-Bisch, 2001) nie tylko współtworzą ład społeczno-ekonomiczny poszczególnych państw, ale także wpływają na kierunki prowadzonych przez nie polityk za pomocą instrumentów finansowych (pożyczki) lub wywierając na rządy (ekspercką) presję. Neoinstytucjonaliści dowodzą, że działanie procesów transnarodowych wspieranych przez transnarodowe organizacje prowadzi do strukturalnej homogeniczności pomiędzy krajami (Abott i DeViney 1992; Boli 1987; Meyer, Ramirez i Soysal 1992; Ramirez i Weiss 1979; Strang 1990), co dotyczy zwłaszcza dziedziny edukacji (Meyer 1977; Ramirez i Meyer 1980; Chabbott i Ramirez 2000; Goldman 2001; Meyer, Frank, Hironka, Schofer i Tuma 1997), nauki (Drori 1998), ochrony środowiska (Frank, Hironka i Scho- 
fer 2000; Goldman 2001; Meyer i in. 1997), polityki społecznej (Room 2000), praw człowieka, w tym praw kobiet (Orloff 1993).

Proces stopniowej konwergencji narodowych systemów odnosi się również do szkolnictwa wyższego. Jego fundamentem jest wspólne podłoże kulturowe, które ułatwia i legitymizuje dyfuzję, zwłaszcza gdy aktorów można zakwalifikować do tej samej kategorii teoretycznej. Polityczne i organizacyjne innowacje najlepiej rozprzestrzeniają się dzięki temu, że aktorzy ci pod wieloma względami są do siebie podobni kulturowo i instytucjonalnie. Ważna jest także asymetria władzy pomiędzy organizacjami rozprzestrzeniającymi innowacje oraz je przyjmującymi. Im państwo jest politycznie słabsze, mniej samodzielne w tworzeniu własnej polityki, tym bardziej staje się podatne na impulsy płynące z zewnątrz, tym łatwiej przyjmuje zewnątrzsterowny model polityki. Niemożność samodzielnego inicjowania oraz implementowania zmian politycznych czy instytucjonalnych skazuje na poszukiwanie nowych modeli, a przede wszystkim ich legitymizację na zewnątrz. Dotyczy to głównie państw niezdolnych do przeprowadzenia reform, które potrzebują zewnętrznego wsparcia, a niekiedy także presji, bowiem centralne rządy nie dysponują wystarczającą ilością społecznych i politycznych zasobów do implementacji reform. Jednocześnie kraje i organizacje mogą być zainteresowane absorbowaniem napływających z zewnątrz innowacji (Strang i Meyer 1993).

Trzecią okolicznością sprzyjającą dyfuzji jest teoretyczność, na którą składają się: abstrakcyjna forma przedmiotu dyfuzji, uteoretycznienie przyjmujących innowacje, uteoretycznienie mechanizmów dyfuzji. Abstrakcyjna forma przedmiotu dyfuzji a) ułatwia rozprzestrzenianie się niezależnie od geograficznej odległości i lokalnego kontekstu ze względu na dostęp do oryginalnego wzoru (modelu). Przez wieki uważano, że jedynie geograficzna bliskość, terytorialne sąsiedztwo odgrywa kluczową rolę w procesie rozprzestrzeniania się innowacji, bowiem zjawisko dyfuzji ma charakter przestrzenny. Niemniej rozwój środków komunikacji, a w szczególności ich digitalizacja, spowodowały, że większą uwagę zwrócono na - znany w naukach społecznych - „proces zarażania” (contagion process) - jako główną siłę rozprzestrzeniania się nowych idei oraz instytucji. Gwałtowny postęp technologiczny oraz „kurczenie się” świata powodują, że geograficzna odległość traci na znaczeniu, czego dowodem są zmiany w szkolnictwie wyższym. Teoretyczny model, taki jak „uniwersytet przedsiębiorczy” (Clark 1998), „masowe szkolnictwo wyższe”, „współodpłatność za kształcenie” (Johnstone 1986) czy „społeczeństwo wiedzy” (Stehr 1994), sprzyja dyfuzji, ale również nadaje im pewną legitymizację naukową. David Strang i John Meyer (1993: 500) piszą o tym w następujący sposób: „uteoretyzowanie wyjaśnia dokładnie, dlaczego adaptujący powinien zaadaptować taką formę zachowania, a nie inną [...] dlatego uteoretyzowanie może być traktowane jako forma racjonalnego wyboru”. Teoretyczność b) może oznaczać ujęcie populacji adaptujących innowacje we wspólną abstrakcyjną kategorię. Podobne rozwiązania in- 
stytucjonalne podlegają rozpowszechnianiu, gdy odbiorców można zakwalifikować do wspólnej teoretycznej kategorii (np. kraje demokratyczne, rozwinięte, nowoczesne). Jak pisze Maria-José Vieira (2004: 491), „czasami jednak te oczekiwania są bezpośrednio i dosłownie implementowane, jeśli dany kraj chciałby stać się krajem nowoczesnym oraz cywilizowanym, a przynajmniej być politycznie traktowany jako taki”. Trzeci aspekt c) dotyczy uteoretyzowania mechanizmów dyfuzji, a w zasadzie ról społecznych osób legitymizujących własnym profesjonalnym (akademickim lub eksperckim) autorytetem określony kierunek lub mechanizm przemian, ułatwiając jego rozpowszechnianie oraz adaptację. W wielu przypadkach dyfuzja innowacji zachodzi w obrębie mniej lub bardziej sformalizowanych sieci specjalistów w danej dziedzinie, dla których pozycja osoby/instytucji legitymizującej dane innowacje jest ważnym argumentem. Eksperci, pracownicy akademiccy czy konsultanci podróżują po całym świecie, stając się ambasadorami zmian, a ich profesjonalny status legitymizuje ich wprowadzanie. Dotyczy to ekspertów zajmujących się zarówno transformacją przedsiębiorstw, jak i transformacją krajów, a zwłaszcza prowadzonych przez nie polityk.

\section{Optyka neoinstytucjonalna w badaniach nad szkolnictwem wyższym}

Optyka neoinstytucjonalna pozwala ujrzeć przemiany w szkolnictwie wyższym w nowej perspektywie i dostrzec w nich efekt procesów politycznych zachodzących na poziomie makrostrukturalnym. Jednocześnie wpływ transnarodowych procesów na kształtowanie się lokalnego porządku jest szczególnie widoczny w obszarze szkolnictwa wyższego ze względu na rosnące w siłę procesy globalizacyjne (van der Wende 2010) . Dotyczy to zwłaszcza polityki publicznej oraz kształtowania narodowych (lokalnych) struktur systemów szkolnictwa wyższego, które - według Johna Meyera, Johna Boli czy Francisca Ramireza (Thomas, Meyer, Ramirez i Boli 1987; DiMaggio i Powell 1983; Meyer i Rowan 1977) ewoluują - mimo znaczących różnic historycznych - w podobnym kierunku poprzez „stopniowe nabywanie wspólnych charakterystyk gdyż [ponadnarodowe - D.A.] trendy popychają je w stronę wspólnego modelu" (Bleiklie 2007: 395).

Od drugiej połowy XX wieku szkolnictwo wyższe (zwłaszcza w Europie) przeszło ogromne przeobrażenia, które zmierzają w kierunku strukturalnej konwergencji narodowych systemów mimo ich historycznych odmienności, będących wynikiem przejścia od kosmopolitycznych idei średniowiecznego uniwersytetu do nowoczesnych systemów narodowego szkolnictwa wyższego kształtowanego w XVIII i XIX wieku. Uczelnie (uniwersytety oraz inne szkoły wyższe) zaczęły stosować logikę formujących się nowoczesnych państw narodowych i zostały podporządkowane ich biurokratycznemu aparatowi. Stąd też nieprzypadkowe jest ukształtowanie się 
w tym okresie trzech zasadniczo odmiennych modeli nowoczesnego uniwersytetu: francuskiego, niemieckiego, anglosaskiego (brytyjskiego) ${ }^{1}$, które odwzorowywały logikę funkcjonowania ówczesnych państw (Antonowicz 2005). Włączenie uczelni w struktury państwowe (poza modelem anglosaskim) spowodowało, że uczelnie na nowo zostały zorganizowane, zgodnie z biurokratyczną logiką funkcjonowania nowoczesnego państwa. Potrzeby formujących się państw zaczęły określać cel funkcjonowania instytucji akademickich, które uległy procesowi nacjonalizacji, stając się swoistymi „laboratoriami nacjonalizmu” (Reisner 1922), wspierającymi proces państwotwórczy i narodotwórczy. Tym samym uczelnie były z jednej strony wpisane w uniwersalny stan wiedzy oraz paradygmaty jej odkrywania, a z drugiej - ich struktura i wzory działania odzwierciedlały instytucjonalne ramy lokalnego ładu politycznego, od których były silnie zależne finansowo i politycznie. Na tę dwoistą naturę uniwersytetów wskazują analizy prowadzone przez Ramireza (2003; 2006a; 2006b), uwypuklające paradoksy funkcjonowania instytucji akademickiej w dwóch niejako równoległych porządkach.

Pierwsze oznaki konwergencji systemów szkolnictwa wyższego pojawily się dopiero w latach 6o. XX wieku wraz z nasileniem się procesów globalizacyjnych, na kanwie których popularność zdobyła teoria kapitału intelektualnego (Schultz 1963), a wraz z nią rozprzestrzenił się masowy model szkolnictwa wyższego towarzyszący idei państwa opiekuńczego. Wzrost liczby studentów widoczny był we wszystkich krajach. Jego dynamika jest znacznie większa w krajach silnie zakorzenionych w społeczeństwie światowym (Schofer i Meyer 2005), a słabsza w krajach będących na jego peryferiach czy leżących poza nim. Ekspansja szkolnictwa wyższego jest jedną z najważniejszych zmian, jakie zaszły w okresie minionego stulecia, a umasowienie stopniowo docierało również do krajów rozwijających się czy wręcz biednych, jak np. Bostwana (Meyer, Nagel i Snyder 1993), w których struktura narodowych gospodarek miała charakter wczesnoindustrialny, a niekiedy jeszcze agrarny. Co więcej, żaden z krajów nie zdecydował się zatrzymać ekspansji szkolnictwa wyższego, mimo pojawiających się głosów krytyki związanych z nasilaniem się zjawiska overeducation (Burris 1983; Büchel, de Grip i Mertens 2003; Antonowicz 2007) oraz frustracji wynikających z niespełnionych aspiracji absolwentów uczelni. Ekspansja szkolnictwa wyższego stała się nie tylko przykładem dyfuzji masowego modelu szkolnictwa wyższego widocznej we wzroście liczby studentów (Schofer i Meyer 2005), ale również konwergencji struktury ich kształcenia w poszczególnych krajach (Gabler i Frank 2005; Drori i Moon 2006; Brint 2002; Ramirez i Wotipka 2001; Ramirez 2006a). Jest to wynik ponadnarodowych procesów politycznych - takich jak choćby proces boloński - sprzyjających strukturalnej homogenizacji szkolnictwa wyższego, które przestawało być

${ }^{1}$ Można też wskazać amerykański model uniwersytetu, który ukształtował się w zupełnie innych warunkach społecznych, politycznych i ekonomicznych. 
wyłącznie domeną rządów państw narodowych, poprzez stopniowe otwieranie się na świat. Uruchomiło to proces denacjonalizacji szkolnictwa wyższego (Teichler 1999), w wyniku którego następowała dyfuzja politycznych modeli, przyspieszająca izomorfizm systemów szkolnictwa wyższego, które przez dekady funkcjonowały jako oddzielne, niekompatybilne systemy. Konwergencja następowała stopniowo zarówno w sferze ideowej (politycznych narracji stojących za polityką publiczną), ustrojowej, a także organizacyjnej, u podstaw której leży racjonalne zachowanie funkcjonujących w międzynarodowej przestrzeni aktorów, zwłaszcza państw narodowych oraz uczelni. Poprzez aktywność transnarodowych organizacji definiowanych jako agenci społeczeństwa światowego (agents of world society) (Meyer i in. 1997; Ramirez i Meyer 1980; Boli i Thomas 1997) nowy porządek ideowy oraz instytucjonalny zyskał cechy normatywne, a w jego konsekwencji logika stosowności zaczęła wyznaczać kierunki polityki publicznej poszczególnych krajów. Po okresie dominacji egalitarnych idei, których uosobieniem był masowy model szkolnictwa wyższego, nastąpiło przechylenie w stronę procesu urynkowienia zakorzenionego w zyskującej ogromne wpływy ekonomicznej teorii racjonalnego wyboru (Downs 1957). W jej wyniku polityce publicznej wobec szkolnictwa wyższego nadano ewaluacyjny kształt (Neave 1988), zaś jej odbiciem na poziomie instytucjonalnym stał się uniwersytet przedsiębiorczy (Clark 1998; Williams 2003).

Proces konwergencji centralnych obszarów funkcjonowania szkolnictwa wyższego nabrał dynamiki w wyniku postępującego umiędzynarodowienia (van der Wende 2010), a polityki publiczne i uczelnie stanęły w obliczu konieczności dostosowania własnych struktur, celów oraz sposobów ich realizacji do wymogów międzynarodowych rankingów, akredytacji, ewaluacji czy potrzeb uzyskania globalnych certyfikatów jakości, takich jak choćby AACB w naukach ekonomicznych. Ład światowy zyskał charakter porządku normatywnego, do którego państwa, ich polityki publiczne, a przede wszystkim uczelnie się dostosowują (kierując się logiką stosowności). Naturalnie „normatywność” tego porządku kształtowana jest przez najsilniejszych aktorów, którzy również przy pomocy organizacji transnarodowych szukają jego legitymizacji. Sprzyja temu rosnąca rola organizacji transnarodowych, zwłaszcza OECD i Banku Światowego, których ogromna siła polityczna wynika nie tylko z posiadanych zasobów finansowych, ale przede wszystkim z autorytetu w sprawach profesjonalnych (Krücken i Meier 2006).

Generalnie wpływ transnarodowych organizacji jest obserwowalny w niemal wszystkich aspektach życia społecznego. Na rosnące znaczenie transnarodowych organizacji, zwłaszcza tych o charakterze pozarządowym (international non-governmental organizations - INGO), wskazują Boli i Thomas (1997: 172). Organizacje te są szczególnym fenomenem społecznym, bowiem posiadając ograniczone zasoby finansowe i korzystając z eksperckiego autorytetu oraz politycznej niezależności (lub takiego wizerunku), mają istotny wpływ na tworzenie się ponadnarodowych zasad, promowanie ładu społecznego i propagowanie wartości reprezentują- 
cych szeroko rozumiany humanizm. Jednak fenomen transnarodowych organizacji nie ogranicza się do ogólnoludzkich wartości promowanych przez takie organizacje, jak Green Peace czy Amnesty International. Transnarodowych organizacji jest znacznie więcej, a ich działanie nie ogranicza się wyłącznie do promowania ogólnoludzkich wartości, przeciwnie - odgrywają one coraz ważniejszą rolę w kształtowaniu polityki publicznej, a w niektórych jej obszarach ta rola jest dominująca. Jak ujął to Wayne Parsons (1996: 234):

Światowa gospodarka zmienia się pod wpływem transformacji w sposobach produkcji i wymiany, a wraz z nią rosną w silę międzynarodowe korporacje oraz instytucje, osłabiając możliwość samodzielnego formułowania polityki publicznej przez państwa narodowe. Współcześnie polityka polityczna tworzona jest zarówno na poziomie systemu światowego, jak i na poziomie państw narodowych.

Wskazywane są tu transnarodowe organizacje, takie jak Międzynarodowy Fundusz Walutowy (MFW), Bank Światowy (BŚ), OECD (Organizacja Współpracy Europejskiej i Rozwoju) czy Unia Europejska (UE). One nie tylko współtworzą ład społeczno-ekonomiczny poszczególnych państw, ale także wpływają na prowadzone przez nie polityki, promując określone kierunki oraz wywierając (ekspercką) presję na państwach przy ich implementacji. Ze względu na asymetrię władzy siła oddziaływania transnarodowych organizacji najbardziej widoczna jest w krajach rozwijających się, także w obszarze szkolnictwa wyższego i badań naukowych. Marek Kwiek (2010: 22) wskazuje, że nigdy wcześniej we współczesnej historii poszczególne aspekty szkolnictwa wyższego nie były tak szczegółowo porównywane przez ośrodki analityczne międzynarodowych organizacji rządowych i pozarządowych. Rocznie każda z wiodących organizacji, takich jak OECD, BŚ czy KE, wydaje kilkadziesiąt publikacji, analiz i raportów poświęconych wybranym aspektom funkcjonowania szkolnictwa wyższego czy nawet pojedynczych uczelni.

Szkolnictwo wyższe coraz silniej podlega procesowi internacjonalizacji, czego naturalną konsekwencją jest rosnący wpływ międzynarodowego ładu na kształtowanie się polityki publicznej, ale również jego bezpośrednie oddziaływanie na strategie funkcjonowania poszczególnych uczelni. Takie założenie winno skłaniać do krytycznej refleksji na temat wyboru perspektywy badawczej nad przemianami zachodzącymi w polskim szkolnictwie wyższym i doboru teoretycznych ram interpretacyjnych, tak aby umożliwiały zrozumienie mechanizmów jego transformacji.

\section{Historyczne uwarunkowania współczesnych przemian w polskim szkolnictwie wyższym}

W ramach prezentowanej perspektywy neoinstytucjonalnej zwraca się uwagę głównie na proces konwergencji systemów szkolnictwa wyższego, dostrzegając w nich 
emanację globalnego porządku. Jednak rzadko zdarza się prosta implementacja nowych struktur, są one raczej „filtrowane” i dopasowywane do lokalnej specyfiki (Meyer i in. 2011; Meyer i Rowan 2012). Ilustruje to nawet pobieżna analiza europejskiego szkolnictwa wyższego, pokazująca wiele różnic w funkcjonowaniu uczelni w poszczególnych krajach, które neoinstytucjonaliści przypisują wpływowi historycznych oraz współczesnych uwarunkowań na funkcjonowanie szkolnictwa wyższego. Jest to określane mianem zależności od ścieżki (path dependency) (Mahoney 2001) i tłumaczy ogromną różnorodność form adaptacji istniejących w przestrzeni transnarodowej idei oraz paradygmatów do lokalnych uwarunkowań społecznych i instytucjonalnych. Anja Jakobi (2007) przedstawia ciekawą analizę odmiennych sposobów definiowania oraz adaptacji koncepcji społeczeństwa wiedzy w różnych uwarunkowaniach społecznych i instytucjonalnych.

Szkolnictwo wyższe nie jest fenomenem osadzonym w ustrojowej oraz instytucjonalnej próżni, co ma poważne metodologiczne konsekwencje dla badań prowadzonych w tym obszarze. Stąd jego przemian nie sposób analizować bez uwzględnienia historycznego podłoża, z którego wyrosło współczesne środowisko instytucjonalne, ale również sposób myślenia o uczelniach. Im silniej jest zinstytucjonalizowane podłoże, na którym wprowadzane są innowacje, tym większy jest wpływ „ścieżki”, a więc swego rodzaju „dziedzictwa przeszłości”. Ilustracją tego zjawiska jest funkcjonowanie przedsiębiorczego modelu uczelni w polskim szkolnictwie wyższym, który z powodzeniem zaistniał w instytucjonalnej próżni sektora niepublicznego, zaś w przypadku uczelni publicznych został zaadaptowany w bardzo specyficzny sposób, bo polscy uczeni stali się przedsiębiorczy, ale ustrój uniwersytetu pozostał oparty na (oligarchicznej) demokracji reprezentacyjnej. Paradoks polega na tym, że oba sektory łączy specyficzna „unia personalna” (Ratajczak 2004) - osoby pracujące w sektorze niepublicznym posiadały główne zatrudnienie (pierwszy etat) w uczelniach publicznych. Tak więc to, co było możliwe, a nawet łatwe do zaakceptowania w kontekście uczelni niepublicznych, zostało niemal całkowicie (koncepcyjnie) odrzucone w uniwersytetach publicznych jako sprzeczne z ideą akademickości. Dla środowiska naukowego wspieranie modelu „uniwersytetu jako wspólnoty badaczy" (Kwiek 2014) jest koniecznym warunkiem utrzymania uniwersyteckiej autonomii (Antonowicz i Jongbloed 2015). Silne przywiązanie do „demokratycznego ustroju” uniwersyteckiego można tłumaczyć historią długiego konfliktu pomiędzy władzami wpierw sanacyjnymi, a następnie komunistycznymi oraz środowiskiem naukowym, u podstaw którego leżała właśnie samorządność instytucji akademickich.

Ogólny wniosek, jaki można z tego wyprowadzić, brzmiałby następująco: pomimo czerpania ze wspólnych idei i implementacji tych samych modeli instytucjonalnych szkolnictwo wyższe w poszczególnych krajach europejskich różni się od siebie formami organizacyjnymi. Idee czy modele instytucjonalne trafiają na silnie zinstytucjonalizowane podłoże, które przez dekady, a nawet wieki, zdołało wykształcić 
unikalne wzory funkcjonowania, zbudować akademickie mity oraz - wskutek kolektywnego doświadczenia - ramy interpretacyjne, które nadają znaczenie kierunkowi współczesnych przemian.

Ilustracją tego zjawiska jest sprawa autonomiczności uczelni rozumianej jako samorządność społeczności uczelnianej do powoływania i odwoływania władz rektorskich. W okresie PRL-u kwestia niezależności władz rektorskich była przedmiotem ostrych sporów między środowiskiem akademickim a władzami partyjno-państwowymi. Demokratyczny wybór władz uczelni - choć jest tylko jednym z wymiarów autonomii instytucjonalnej - urósł w ten sposób do rangi symbolu niezależności środowiska naukowego, a jej obrona przybrała martyrologiczne szaty. Władze komunistyczne, chcąc symbolicznie „ukarać” i na swój sposób zdyscyplinować środowisko naukowe, odbierały uczelniom uprawnienia do samorządności, stąd przepisy o niezależności rektora od władz państwowych zyskały charakter symbolu (Antonowicz 2015a).

Demokratyczny przełom 1989 r. i będąca jego pokłosiem ustawa Prawo o szkolnictwie wyższym z 1990 r. gwarantowały uczelniom pełną autonomię w wyborze swoich władz. Przepisy legislacyjne w tym kształcie przetrwały aż do czasu uchwalenia nowej ustawy (w 2005 r.) i zapewne nic by się w tej kwestii nie zmieniło, gdyby nie przypadek kryminalnej aktywności Antoniego Jarosza, rektora Państwowej Wyższej Szkoły Zawodowej w Jarosławiu, w wyniku której został on skazany za spowodowanie wypadków samochodowych, nakłanianie do fałszywych zeznań oraz wykorzystanie seksualne i finansowanie z pieniędzy uczelni własnej kampanii do Senatu. Mimo symbolicznego wymiaru ustawowo gwarantowanej niezależności władz uczelni środowisko rektorów zgodziło się przyjąć (w drodze wyjątku) zapis w art. 38 ustawy Prawo o szkolnictwie wyższym - określany popularnie casusem Jarosza - który brzmi następująco:

5. W przypadku rażącego naruszenia prawa przez rektora minister właściwy do spraw szkolnictwa wyższego może odwołać rektora po zasięgnięciu opinii Rady Głównej Szkolnictwa Wyższego oraz odpowiednio Konferencji Rektorów Akademickich Szkół Polskich albo Konferencji Rektorów Zawodowych Szkół Polskich i wyznaczyć termin do przeprowadzenia wyborów uzupełniających.

Wprawdzie dokonano pewnego wyłomu, ale jednocześnie zobligowano ministra do zasięgnięcia opinii organów przedstawicielskich środowiska naukowego. W 2009 r. ówczesna minister nauki i szkolnictwa wyższego Barbara Kudrycka wprowadziła do ustawy zapis umożliwiający zawieszenie władz rektorskich w przypadku, gdyby finansowa sytuacja uczelni była tragicznie zła i nie rokowała poprawy, tj. w sytuacji gdy „suma strat netto w okresie nie dłuższym niż pięć ostatnich lat przekracza $25 \%$ kwoty dotacji z budżetu państwa otrzymanej w roku poprzedzającym bieżący rok budżetowy na zadania, o których mowa w art. 94 ust. 1 pkt 1" (100a) oraz wprowadzony program naprawczy nie stwarzał realnych szans na po- 
prawę sytuacji finansowej, w takiej sytuacji nowelizacja przewidywała możliwość powołania przez ministra „na okres nie dłuższy niż trzy lata, osobę pełniącą obowiązki rektora, powierzając jej zadania dotyczące opracowania i wdrożenia programu naprawczego", której powołanie powoduje następujące konsekwencje:

- dotychczasowy rektor uczelni publicznej zostaje zawieszony w pełnieniu obowiązków; w okresie zawieszenia rektorowi nie przysługuje dodatek funkcyjny do wynagrodzenia;

- zawieszona zostaje działalność organów kolegialnych uczelni publicznej w zakresie decydowania o gospodarce finansowej, w szczególności w zakresie kompetencji określonych $\mathrm{w}$ art. 90 ust. 4; pozostałe kompetencje organów kolegialnych są realizowane na zasadach dotychczasowych;

- „osoba pełniąca obowiązki rektora staje się przewodniczącym senatu uczelni publicznej" (PSW 100a, pkt 6).

Pomysł ten został całkowicie odrzucony przez środowisko naukowe, które oskarżało minister Barbarę Kudrycką o autorytarne skłonności, porównując ten zapis z niechlubną praktyką odwoływania rektorów w okresie stalinowskim. Wprawdzie Kudrycka zdołała ten przepis przeforsować w parlamencie, ale za cenę skrajnej niepopularności czy wręcz ostentacyjnej niechęci środowiska akademickiego. Pokazuje to, że nie tylko siła globalnych procesów, wsparta autorytetem i zasobami finansowymi transnarodowych organizacji, ale i „duch przeszłości” ma istotne znaczenie w kształtowaniu współczesnych systemów szkolnictwa wyższego. Nie dotyczy to przy tym tylko Polski, krajów Europy Środkowo-Wschodniej czy krajów z autorytarną przeszłością. Siła oddziaływania lokalnych porządków instytucjonalnych została ukazana w pracach Petera Maassena i Åse Gornitzkiej (2012), którzy przeanalizowali różnice pomiędzy systemami szkolnictwa wyższego krajów nordyckich wynikające $\mathrm{z}$ ich historii. Instytucje - w szerokim znaczeniu tego słowa - są najtrudniejszymi do zmiany elementami systemu szkolnictwa wyższego, są w nim bowiem najgłębiej zakorzenione.

Historia staje się kluczem do zrozumienia wielu współczesnych zjawisk zachodzących w szkolnictwie wyższym, zwłaszcza środowiskowej interpretacji transnarodowych trendów czy organizacyjnych innowacji, które przychodząc z zewnątrz, muszą się wpisać w silnie zinstytucjonalizowane środowisko, ale przede wszystkim zawsze będą odczytywane przez pryzmat wspólnych doświadczeń środowiskowych, które wywarły głęboki wpływ nie tylko na porządek instytucjonalny, ale przede wszystkim na relacje łączące rządzących z samym środowiskiem naukowym. Stąd znajomość historii nie tyle ułatwia przewidywanie kierunku zmian polityki publicznej - ten jest bowiem określany na poziomie transnarodowym, ile pozwala zrozumieć sposób ich adaptacji do lokalnych, w tym przypadku polskich, warunków. Historia jest ważnym filtrem interpretacyjnym i punktem odniesienia przy ocenie oraz środowiskowej interpretacji politycznych inicjatyw przeprowadzanych w tym obszarze. 


\section{Przemiany polskiego szkolnictwa wyższego (1989-2014) w optyce globalnej}

Neoinstytucjonalna perspektywa analiz przemian w szkolnictwie wyższym różni się od dotychczasowych ram teoretycznych tym, że w badaniach zwraca szczególną uwagę na sposób adaptacji globalnych trendów i innowacji do lokalnych warunków, zakładając, że to on w istocie ma decydujący wpływ na kierunek i dynamikę przebiegu transformacji szkolnictwa wyższego. Oznacza to, że w centrum zainteresowania badawczego znajduje się sposób interpretacji transnarodowych procesów przez głównych aktorów, który trudno uchwycić na poziomie analiz mikro czy mezo, choć te drugie na pewno ułatwiają zaobserwowanie wielu niedostrzegalnych zazwyczaj zdarzeń, faktów, aspektów specyficznych dla lokalnego porządku, co znacząco wzbogaca wiedzę. Należy jednak zauważyć, że nadmierna koncentracja na detalach powoduje zamazanie czy wręcz utracenie „wielkiego obrazu”, który ułatwia dostrzeżenie mechanizmów i prawidłowości kierujących procesem transformacji szkolnictwa wyższego. Tym samym optyka makrostrukturalna odchodzi od badania przemian w latach 1989-2014 jako odosobnionego (unikalnego) procesu, proponując traktowanie polskiego szkolnictwa wyższego jako części zmian zachodzących w globalnym porządku (world polity), a zmierzających w stronę izomorfizmu. Z tego powodu to w społeczeństwie światowym i wspierających go transnarodowych organizacjach upatruje się źródła zmian, a globalne modele instytucjonalne niejako formują lokalne struktury szkolnictwa wyższego (względnie wpisują się w lokalny porządek instytucjonalny), oferując im gotową polityczną czy instytucjonalną matrycę. Pozwala to dostrzec w lokalnym porządku przede wszystkim emanację/odwzorowanie reguł i znaczeń zaczerpniętych z globalnych abstrakcyjnych modeli, które w dużej mierze pozostają niezależne od lokalnych uwarunkowań (Thomas i in. 1987; Meyer i in. 1997; Jepperson 2002; Hasse i Krücken 2005).

Polskie szkolnictwo wyższe stało się areną ścierania się dwóch porządków (globalnego i lokalnego) oraz przystosowywania się do transnarodowych procesów. Wśród zjawisk kształtujących XX-wieczne szkolnictwo wyższe znajdują się przede wszystkim: a) zachodzące już od lat 50. umasowienie (Trow 1970), b) rozpoczęte w latach 80. urynkowienie (Clark 1998; Jabłecka 2002) oraz c) widoczna od lat 90. denacjonalizacja szkolnictwa wyższego (Teichler 1999; van der Wende 2010). Ich działania odcisnęły swoje piętno na funkcjonowaniu współczesnego szkolnictwa wyższego, a zwłaszcza jego relacjach z państwem, powodując całkowite i zapewne bezpowrotne zmiany. Jednocześnie wszystkie te procesy - po otwarciu się Polski na świat - zaczęły aktywnie kształtować polską politykę publiczną, wpływać na nowo tworzony porządek instytucjonalny, a także bezpośrednio (poprzez legislacje, politykę personalną i finansową) oraz pośrednio (poprzez gęstą sieć relacji między uczelniami, uczonymi i studentami z różnych krajów) na sposób funkcjonowania 
uczelni i środowiska naukowego. W tym sensie takie zjawiska, jak: adaptacja procesu bolońskiego, przywiązanie do demokratycznego wyboru władz uczelni publicznych czy upór w utrzymywaniu w strukturze stopni stopnia doktora habilitowanego, nabierają zupełnie innego, ponadlokalnego wymiaru. Nawiązując do przesłania płynącego ze Zjazdu Polskiego Towarzystwa Socjologicznego w 1994 r., można powiedzieć, że transformacja polskiego szkolnictwa wyższego stała się doskonałą okazją do testowania (np. neoinstytucjonalnej) teorii, ale i konieczności tworzenia nowych, które będą miały większą moc wyjaśniającą. Wpływ społeczeństwa światowego na formowanie się lokalnego porządku instytucjonalnego jest szczególnie widoczny w przypadku szkolnictwa wyższego, które z jednej strony wskutek procesów denacjonalizacji stało się podatne na transnarodowe trendy, a z drugiej (w kontekście europejskim) nadal pozostaje mocno zakorzenione w instytucjonalnej tradycji państw narodowych. Jednocześnie dla neoinstytucjonalistów Polska stanowi wyjątkowo ciekawe pole badań nad rozprzestrzenianiem się strukturalnych innowacji w środowiskach silnie zinstytucjonalizowanych, czyli nad adaptowaniem globalnych procesów/zjawisk w obszarze szkolnictwa wyższego (w tym uniwersytetów), które przez dekady wykształciło własne (lokalne) wzory funkcjonowania.

Geopolityczne zmiany, jakie nastąpiły w wyniku demokratycznych przemian w krajach Europy Środkowo-Wschodniej, doprowadziły do upadku pojałtańskiego porządku, w wyniku którego Polska znalazła się po wschodniej stronie „żelaznej kurtyny", a więc w izolacji od globalnych trendów kształtujących szkolnictwo wyższe w krajach Europy Zachodniej. Jak wspominano wcześniej, polscy naukowcy utrzymywali kontakty z zagranicznymi ośrodkami i mimo utrudnień, jakie stwarzały ówczesne władze dla podróżujących po świecie, zagraniczni naukowcy nie tylko bywali w Polsce, ale również (wprawdzie sporadycznie) tłumaczenia ich tekstów ukazywały się w polskich periodykach (np. „Życie Szkoły Wyższej”). Wszystko to jednak odbywało się na poziomie indywidualnym i nie miało wpływu (albo był on bardzo ograniczony) na prowadzoną politykę w sferze nauki i szkolnictwa wyższego. Dopiero przełom demokratyczny pozwolił na zaczerpnięcie z krajów Europy Zachodniej politycznych czy instytucjonalnych rozwiązań, a co ważniejsze - stworzył możliwość ich implementacji. Klasycznym przykładem nowego otwarcia było utworzenie w 1991 r. Komitetu Badań Naukowych, którego struktura i funkcjonowanie odzwierciedlały istniejące $w$ tamtym okresie agencje badawcze we Francji czy Wielkiej Brytanii. Dla neoinstytucjonalistów Europa Środkowo-Wschodnia przez to, że tak długo znajdowała się w politycznej izolacji i nagle otworzyła się na świat - stała się polem do testowania i rozbudowywania własnych teorii. Otwarcie się na świat wsparte jednoznacznie prozachodnim kursem w polityce lat 90. (rozumianym w tych warunkach jako kierowanie się logiką stosowności) spowodowało, że szkolnictwo wyższe zostało wystawione na bezpośrednie działanie społeczeństwa światowego, a wraz z nim na szereg procesów, jakie zachodziły w systemach szkolnictwa wyższego krajów Europy Zachodniej od czasu zakończenia II wojny 
światowej. Dynamika tego otwarcia uczyniła z polskiego szkolnictwa wyższego laboratorium, w którym niemal jak w akceleratorze cząsteczek w podgenewskim CERN można dokładnie obserwować zmiany zachodzące w szkolnictwie wyższym. Jednoznacznie prozachodni kierunek powodował, że procesy adaptacyjne transnarodowych trendów zachodziły znacznie szybciej, bowiem - tak jak to miało miejsce w przypadku procesu bolońskiego (Antonowicz 2015b) - szkolnictwo wyższe było narzędziem integracji Polski ze strukturami europejskimi.

Można wprawdzie powiedzieć, że otwarcie się na świat następowało już w latach 80. i miało charakter stopniowy, jednak w sferze politycznej (polityki publicznej wobec szkolnictwa wyższego) otwarcie nastąpiło wraz ze zmianą reżimu politycznego. Polska została wystawiona na działanie procesów globalnych, a jednocześnie zaczęła prowadzić usilne starania, aby stać się częścią świata zachodniego, to znaczy dołączyć do zachodnioeuropejskich struktur politycznych, gospodarczych i militarnych. Zmiany w tych obszarach następowały tu szybciej, gwałtowniej i bardziej spektakularnie. W odróżnieniu do wielu innych krajów otwierających się na działanie społeczeństwa światowego (takich jak Singapur, Malezja czy Korea, gdzie lokalna tradycja akademicka była słaba) i adaptujących gotowe modele instytucjonalne, przemiany w polskim szkolnictwie wyższym nie zachodziły $w$ instytucjonalnej próżni, a idee oraz modele instytucjonalne przychodzące z zewnątrz były filtrowane i interpretowane przez pryzmat istniejących idei akademickich, kolektywnego doświadczenia środowiska naukowego, a przede wszystkim głęboko zakorzenionego porządku instytucjonalnego.

\section{Konkluzje}

Przemiany w polskim szkolnictwie wyższym to jeden z najciekawszych, choć nadal nie w pełni zbadanych fenomenów, a studia nad nimi wymagają nie tylko spojrzenia z poziomu mikro i mezo, ale również makrosocjologicznych analiz, które będą ukierunkowane na analizę relacji wpływu globalnego porządku na szkolnictwo wyższe. Ścieranie się tych dwóch porządków stało się integralnym elementem procesu transformacji i przejawia się w niemal wszystkich jego aspektach. Z uwagi na to przyjęcie neoinstytucjonalnej perspektywy stwarza nadzieję na lepsze niż dotychczas poznanie mechanizmów adaptacji globalnych trendów politycznych oraz innowacji organizacyjnych do lokalnych uwarunkowań instytucjonalnych, to bowiem według neoinstytucjonalistów jest motorem przemian w szkolnictwie wyższym.

Polskie transformacje szkolnictwa wyższego stanowią okazję do spojrzenia na przemiany z poziomu makro, ale również sposobność do przetestowania neoinstytucjonalnej teorii w warunkach głębokich, żywiołowych i dynamicznych przeobrażeń, które miały miejsce w kraju o bogatej tradycji akademickiej i silnej pozycji społeczności naukowej. Dlatego też badania wpływu społeczeństwa światowego nie 
można dokonywać w oderwaniu od historycznego dziedzictwa polskiego szkolnictwa wyższego, a także politycznych warunków ich funkcjonowania przez niemal cały XX wiek. Wzmocniły one istotnie znaczenie nieformalnych, akademickich czy uczelnianych zwyczajów i obyczajów, które pozwoliły uczelniom w trudnym okresie niedemokratycznych rządów w miarę normalnie funkcjonować. Mity akademickie, historia czy wreszcie środowiskowe doświadczenie tworzą ramy interpretacyjne, poprzez które są postrzegane, a co ważniejsze - również interpretowane współczesne przemiany szkolnictwa wyższego. W środowisku naukowym doświadczenie historyczne tworzy ramy interpretacyjne dla zdarzeń współczesnych, bez znajomości których łatwo o pomyłkę.

\section{Literatura}

Abbott, A., DeViney, S. (1992). The welfare state as transnational event: Evidence from sequences of policy adoption. Social Science History. 16(2): 245-274.

Antonowicz, D. (2005). Uniwersytet przyszłości: wyzwania i modele polityki. Warszawa: Instytut Spraw Publicznych.

Antonowicz, D. (2007). Digital players in the analogue world. Overeducation in the Polish society. W: K. Leja (red.). Management issues in knowledge-based university (21-29). Gdańsk: Wyd. Politechniki Gdańskiej.

Antonowicz, D. (2012). External Influences and Local Responses. Changes in Polish Higher Education 1990-2005. W: P. Maassen, M. Kwiek (red.). National Higher Education Reforms in a European Context: Comparative Reflections on Poland and Norway (87111). Frankfurt am Main: Peter Lang.

Antonowicz, D. (2015a). Między sita globalnych procesów a lokalną tradycją. Toruń: Wyd. UMK.

Antonowicz, D. (2015b). Lost opportunity? The Bologna Process in Poland. Journal of European Higher Education Area. 3: 95-110.

Antonowicz, D., Jongbloed, B. (2015). Jaki ustrój uniwersytetu? Reforma szkolnictwa wyższego w Holandii, Portugalii i Austrii: wnioski dla Polski, Warszawa: EY Polska.

Bleiklie, I. (1998). Justifying the Evaluative State: New Public Management Ideals in Higher Education. European Journal of Education. 33: 299-316.

Bleiklie, I. (2007). Systemic Integration and Macro Steering. Higher Education Policy. 20 : 391-412.

Boguski, J. (2009). Od uniwersytetu przedsiębiorczego do uniwersytetu przyszłości. Nauka i Szkolnictwo Wyższe. 1(33): 25-33.

Boli, J. (1987). World Polity Sources of Expanding State Authority and Organization, 18701970. W: G. Thomas, J. Meyer, F. Ramirez, J. Boli. Institutional Structure: Constituting State, Society and the Individual (71-91). Newbury Park: Sage.

Boli, J., Thomas, G. (1997). World culture in the world polity: A century of international non-governmental organization. American Sociological Review. 62: 171-190.

Brint, S. (2002). The rise of the "practical arts". W: S. Brint (red.). The future of the city of intellect: the changing American university (231-259). Stanford: Stanford University Press. 
Büchel, F., Grip, A. de, Mertens, A. (2003). Overeducation in Europe: Current Issues in Theory and Policy, London: Edward Elgar Publishing.

Burris, V. (1983). The Social and Political Consequences of Overeducation. American Sociological Review. 48(4): 454-467.

Chabbott, C., Ramirez, F. (2000). Development and Education. W: M. Hallinan (red.). Handbook of the Sociology of Education (163-187). New York: Kluwer Press.

Clark, B. (1986). The Higher Education System: Academic Organization in Cross-national Perspective. Berkley: University of California Press.

Clark, B. (1998). Creating Entrepreneurial Universities: Organizational Pathways of Transformation. Issues in Higher Education. Berkley: University of California Press.

DiMaggio, P., Powell, W. (1983). The iron cage revisited: Institutional isomorphism and collective rationality in organizational fields. American Sociological Review. 48: 147-160.

Drori, G. (1998). A Critical Appraisal of Science Education for Economic Development. W: W. Cobern (red.). Socio-Cultural Perspectives on Science Education: An International Dialogue (49-74). Amsterdam: Kluwer Academic Publishing.

Downs, A. (1957). An economic theory of democracy. Boston: Addison Wesley.

Drori, G., Meyer, J., Ramirez, F., Schofer, E. (2003). Science in the Modern World Polity: Institutionalization and Globalization. Berkley: Stanford University Press.

Drori, G., Moon, H. (2006). The changing nature of tertiary education: Cross-national trends in disciplinary enrollment, 1965-1995. W: D. Baker, A. Wiseman (red.). The impact of comparative education research on institutional theory. Greenwich: JAI.

Dziedziczak-Foltyn, A. (2011). Plusy i minusy reformy szkolnictwa wyższego w Polsce - próba analizy debaty publicznej. W: J. Kostkiewicz, A. Domagała-Kręcioch, M.J. Szymański (red.). Szkoła wyższa w toku zmian. Debata wokół ustawy z 18 marca 2011 roku (t. 1, 95-117). Kraków: Impuls.

Frank, D., Hironka, A., Schofer, E. (2000). The Nation State and the Natural Environment over the Twentieth Century. American Sociological Review. 65: 96-116.

Gabler, J., Frank, D. (2005). The natural sciences in the university: Change and variation over the 2oth century. Sociology of Education. 78: 183-206.

Goldman, M. (2001). Constructing an environmental state: eco-governmentality and other trans-national practices of a "green" World Bank. Social Problems. 48(4): 499-523.

Hasse, R., Krücken, G. (2005). Neo-Institutionalismus. Bielefeld: University of Bielefeld.

Jabłecka J. (2002). Menedżeryzm i państwo ewaluacyjne - zmiany w zarządzaniu uniwersytetami na przykładzie Wielkiej Brytanii. W: M. Wójcicka (red.). Dywersyfikacja w szkolnictwie wyższym (63-81). Warszawa: Wyd. Uniwersytetu Warszawskiego.

Jabłecka, J. (2007). Ćwierć wieku reform: o przyczynach i kontekście przemian w zarządzaniu uniwersytetami europejskimi. W: A. Lewicka-Strzałecka (red.). Współczesne wyzwania nauk praktycznych (85-116). Warszawa: Wyd. Wyższej Szkoły Przedsiębiorczości i Zarządzania im. L. Koźmińskiego.

Jakobi, A. (2007). The Knowledge Society and Global Dynamics in Education Politics. European Educational Research Journal. 6(1): 39-51.

Jepperson, R. (2002). Political modernities: disentangling two underlying dimensions of institutional differentiation. Sociological Theory. 20: 61-85. 
Johnstone, B. (1986). Sharing the Costs of Higher Education: Student Financial Assistance in the United Kingdom, the Federal Republic of Germany, France, Sweden, and the United States. New York: College Entrance Examination Board.

Kolasa-Nowak, A. (2005). Polskie studia nad transformacją: kierunki konceptualizacji. Nauka. 4: 117-132.

Kołodko, G. (1992). Transformacja polskiej gospodarki: sukces czy porażka?, Warszawa: BGW.

Kowalik, T. (2000). Wspótczesne systemy ekonomiczne: powstawanie, ewolucja, kryzys. Warszawa: Wyd. Wyższej Szkoły Przedsiębiorczości i Zarządzania im. L. Koźmińskiego.

Krücken, G., Meier, F. (2006). Turning the University into an Organizational Actor. W: G. Drori, H. Hwang, J. Meyer (red.). Globalization and Organization. World Society and Organizational Change (241-257). Oxford: Oxford University Press.

Kwiek, M. (2009). The Two Decades of Privatization in Polish Higher Education. CostSharing, Equity, and Access. W: J. Knight (red.). Financing Access and Equity in Higher Education. Rotterdam - Boston - Taipei: Sense Publisher.

Kwiek, M. (2010). Transformacje uniwersytetu. Zmiany instytucjonalne i ewolucje polityki edukacyjnej w Europie. Poznań: Wyd. Naukowe UAM.

Kwiek, M. (2014). Uniwersytet jako „wspólnota badaczy”? Polska z europejskiej perspektywy porównawczej i ilościowej. Nauka i Szkolnictwo Wyższe. 2(40): 71-100.

Mahoney, J. (2001). Path-Dependent Explanations of Regime Change: Central America in ComparativePerspective.StudiesinComparativeInternationalDevelopment.36:111-141.

March, J., Olsen, J. (2004). The logic of appropriateness. ARENA Working Paper. 9: 1-28.

Marginson, S. (1997). Steering from a distance: Power relations in Australian higher education. Higher Education. 34: 63-80.

Meyer, H., Rowan, B. (2012). The New Institutionalism in Education. Albany: Suny Press.

Meyer, J. (1977). The Effects of Education as an Institution. American Journal of Sociology. 83: 55-77.

Mayer, P. (2011). Higher Education Reform in South Korea and the Transformation of University Governance. W: W. Pascha, C. Storz, M. Taube (red.). Institutional Variety in East Asia (97-115). Cheltenham: Edward Elgar Publishing.

Meyer, J., Boli, J., Thomas, G., Ramirez, F. (1997). World Society and the Nation State. American Journal of Sociology. 103(1): 144-181.

Meyer J., Frank, D., Hironka, A., Schofer, E., Tuma, N. (1997). The Structuring of a World Environmental Regime, 1870-1990. International Organization. 51: 623-651.

Meyer, J., Nagel, J., Snyder, C. (1993). The expansion of mass education in Botswana: Local and world society perspectives. Comparative Education Review. 37(4): 454-475.

Meyer, J., Ramirez, F., Soysal, Y. (1992). World Expansion of Mass Education 1870-1980. Sociology of Education. 65(2): 128-149.

Meyer, J., Rowan, B. (1977). Institutionalized Organizations: Formal Structure as Myth and Ceremony. American Journal of Sociology. 83: 340-363.

Meyer-Bisch, P. (2001). Social Actors and Sovereignty in IGOs. International Social Science Journal. 53: 611-619.

Misztal, B. (2000). Prywatyzacja szkolnictwa wyższego $w$ Polsce: wyzwania $w$ świetle transformacji systemowej. Kraków: Universitas. 
Neave, G. (1998). The Evaluative State Reconsidered. European Journal of Education. 33: 265-284.

Orloff, A. (1993). Gender and the Social Rights of Citizenship: The Comparative Analysis of State Policies and Gender Relations. American Sociological Review. 58: 303-328.

Parsons, W. (1996). Public policy. An Introduction to the Theory and Practice of Policy Analysis. Cheltenham: Edward Elgar.

Pawłowski, K. (2004). Społeczeństwo wiedzy. Szansa dla Polski. Kraków: Znak.

Ramirez, F. (2003). Women in Science/Women and Science: Liberal and Radical Perspectives. W: T. Wobbe (red.).Zwischen Vorderbühne und Hinterbühne: Beiträge zum Wandel der Geschlechterbeziehungen in der Wissenchaft (279-305). Bielefeld: Transcript.

Ramirez, F. (2006a). The Rationalization of Universities. W: M.-L. Djelic, K. Sahlin-Andersson (red.). Transnational Governance: Institutional Dynamics of Regulation (225245). Cambridge: Cambridge University Press.

Ramirez, F. (2006b). Growing Commonalities and Persistent Differences in Higher Education: Universities Between Globalization and National Tradition. W: H. Meyer, B. Rowan (red.). The New Institutionalism in Education: Advancing Research and Policy (123-141). Albany: Suny Press.

Ramirez, F., Meyer, J. (1980). Comparative education. The social construction of the modern world system. Annual Review of Sociology. 6: 369-399.

Ramirez, F., Weiss, J. (1979). The political incorporation of women. W: J. Meyer, M. Hannan (red.). National Development and the World System (238-249). Chicago: University Chicago Press.

Ramirez, F., Wotipka, C. (2001). Slowly But Surely? The Global Expansion of Women's Participation in Science and Engineering Field of Study, 1972-1992. Sociology of Education. 74: 231-251.

Ratajczak, M. (2004). Unia personalna. Forum Akademickie. 2: 26-29.

Reisner, E. (1922). Nationalism and Education since 1789: A social and political history of modern education. New York: Macmillam.

Room, G. (2000). Globalisation, social policy and international standard-setting: The case of Higher Education credentials. International Journal of Social Welfare. 9(2): 103-119.

Schofer, E., Meyer, J. (2005). The Worldwide Expansion of Higher Education in the Twentieth Century. American Sociological Review. 70(6): 898-920.

Schultz, T. (1963). The Economic Value of Education. New York: Columbia University Press.

Scott, P. (red.). (1998). The Globalization of Higher Education. Buckingam: Society for Research into Higher Education \& Open University Press.

Sosnowska, A. (1998). Teorie zmiany i rozwoju społecznego a zmiany w Europie Wschodniej. O potrzebie perspektywy globalnej. Kultura i Społeczeństwo. 1: 61-72.

Stark, D. (1992). Od systemowej tożsamości do organizacyjnej różnorodności. Przyczynek do analizy zmiany społecznej w Europie Wschodniej. Studia Socjologiczne. 3-4: 53-63.

Stehr, N. (1994). Knowledge Societies. London: Sage.

Strang, D. (1990). From dependency to sovereignty: an event history analysis of decolonization. America Sociological Review. 55: 846-860.

Strang, D., Meyer, J. (1993). Institutional conditions for diffusion. Theory and Society. 22(4): 487-511. 
Teichler, U. (1999). Internationalisation as a challenge for higher education in Europe. Tertiary Education and Management. 5(1): 5-22.

Thomas, G., Meyer, J., Ramirez, F., Boli, J. (1987). Institutional Structure: Constituting the State, Society, and the Individual. Newbury Park: Sage.

Trow, M., (1970). Reflections on the Transition from Mass to Universal Higher Education. Daedalus. 99(1): 1-42.

Vieira, M.-J. (2004). Globalization and Higher Education Organizational Change: A framework for analysis. Higher Education. 48: 483-510.

Wallerstein, I. (1974). The modern world-system, Studies in social discontinuity. New York: Academic Press.

Wallerstein, I. (2011). Capitalist agriculture and the origins of the European world-economy in the sixteenth century: with a new prologue, Berkley: University of California Press.

Wende, M. van der (2010). Internationalization of higher education. Internationalization of higher education. W: P.L. Peterson, E.L. Baker, B. McGaw (red.). International Encyclopedia of Education (540-545). Oxford: Elsevier.

Williams, G. (red.) (2003). The enterprising university: reform, excellence and equity. Buckingham: SRHE and Open University Press.

Wilkins, S., Huisman, J. (2011). The international branch campus as transnational strategy in higher education. Higher Education. 64(5): 627-645.

Zarycki, T., (2009). Peryferie: nowe ujęcia zależności centro-peryferyjnych. Warszawa: Scholar.

\section{The new institutional perspective in Polish higher education research}

ABSTRACT. The aim of the paper is to explore the use of the new institutional perspective in the research of transformation of the Polish higher education. The paper viewpoint is that world society exercises massive influence on national systems of higher education and they tend to evolve into system convergence. This process is particularly well observed in countries like Poland that after decades of isolation became widely exposed to transnational trends which in the past had shaped higher education systems in western countries. The paper tries to demonstrate that a) the Polish higher education system creates a unique opportunity for neo-institutional theory to be critically tested in situation of rapid, spontaneous and dynamic changes that is taking place in the country of long and well-established academic tradition as well as a strong position of the academic community; b) the paper also makes a methodological claim by stating that any analysis that aspire to understand current discussions, conflicts and developments in the Polish higher education cannot ignore its past legacy. To contrary, they need to take seriously into account well institutionalized academic institutions, customs and habits that helped academics to keep universities going under undemocratic conditions.

KEYWORDS: neoinstitionalism, higher education, transformation, Poland

CYTOWANIE: Antonowicz, D. (2015). Między globalnymi siłami i lokalnym porządkiem. Ewolucja mechanizmów sterowania polskim szkolnictwem wyższym w latach 1989-2014. Nauka i Szkolnictwo Wyższe. 1(45): 75-94. DOI: 10.14746/nsw.2015.1.3 